\title{
Najbardziej intymna tęsknota - Polska w korespondencji Józefa Czapskiego
}

\section{The Most Intimate Longing - Poland in the Correspondence of Józef Czapski}

\begin{abstract}
The article discusses Józef Czapski's patriotism as reflected in his correspondence. The appropriate context is provided with the use of the artist's interviews, journal entries, and essays. In Czapski's case, his deeply internalised sense of Polishness was a conscious and consistently implemented choice, taken despite the fact that many other doors were open to the heir to an aristocratic family with broad European connections. Letters written by Czapski to various people show, on the one hand, a strong emotional bond with Poland, additionally strengthened by the distance forced by emigration and exile and by the memory of those who gave their lives for the country (Katyn), and on the other hand - almost positivist involvement in the service to the Paris-based "Kultura", seen as working for the benefit of the homeland.
\end{abstract}

Keywords: Józef Czapski, patriotism, emigration, Poland

Streszczenie: Artykuł porusza zagadnienie patriotycznej postawy Czapskiego w świetle jego osobistej korespondencji. Jako kontekst wykorzystano wywiady, zapisy dziennikowe i eseistykę artysty. Głęboko uwewnętrznione poczucie polskości w przypadku Czapskiego było świadomym i konsekwentnie realizowanym wyborem, mimo wielu innych możliwości rysujących się przed potomkiem arystokratycznej rodziny o bogatych europejskich koligacjach. Listy do różnych adresatów pokazują z jednej strony silny emocjonalny związek z Polską, dodatkowo wzmocniony emigracyjnym, wygnańczym oddaleniem i pamięcią o tych, którzy jej poświęcili życie (Katyń), z drugiej zaś - niemal pozytywistyczne zaangażowanie w służbie paryskiej „Kulturze” rozumianej jako praca na rzecz Kraju.

Słowa kluczowe: Józef Czapski, patriotyzm, emigracja, Polska

„Wiesz, dobra rozmowa jest, kiedy nie umie się człowiek wypowiedzieć, ale właśnie w tym "niezrozumiałym« komunikuje się wzajemnie. Spotkanie tej 
niebywałości ${ }^{1}$ przeżycia, jego niewypowiadalności, to jest wielki skarb i wielka rzadkość2" - w ten sposób 93-letni Józef Czapski dziękuje Piotrowi Kłoczowskiemu za doświadczenie takiego porozumienia, ujawniając jednocześnie wyczuloną wrażliwość na to, co nieuchwytne, co pojawia się „pomiędzy” słowami, co w obrazach nieobecne, a przywołane na przykład jedynie (!) kadrowaniem ${ }^{4}$, na to, co jest "najważniejsze ${ }^{5}$, co decyduje o wartości - rozmowy, sztuki, ludzkiego istnienia.

Takiej czujności, dostrzegającej owo „niewypowiadalne”, które skryło się „pomiędzy” czy „na zewnątrz”, wymaga lektura tekstów Józefa Czapskiego, a także jego malarstwo, bowiem bardzo rzadko najważniejsze powiedziane jest wprost $^{6}$.

Co więcej, brak owej czujności prowadzić może do nieporozumień, takich jak stwierdzenie, że w przypadku Czapskiego „abstrahowanie od sytuacji twórcy na emigracji wydaje się być świadomym zabiegiem przełamania postawy niemocy czy wydziedziczenia, które często towarzyszyły twórcom emigracyjnym"7.

${ }^{1} O$ niebywatym - to pierwotny tytuł eseju $O$ Haupcie. O znaczeniu tej zmiany tytułu i znaczeniu samego "niebywałego" piszę szerzej w artykule Haupt Czapskiego [w:] Jestem bardzo niefortunnym wyborem. Studia i szkice o twórczości Zygmunta Haupta, red. A. Niewiadomski, P. Panas, Lublin 2018, s. 193-201. Wzorcowym ujęciem nieadekwatności środków wyrazu do wewnętrznego doświadczenia artysty jest wielokrotnie przywoływany przez Czapskiego w dzienniku i w korespondencji List lorda Chandosa, którego fragmenty należały do jego tak zwanych złotych gwoździ. H. von Hofmannsthal, List [w:] tegoż, Księga przyjaciót i szkice wybrane, wybór, tłum. i noty P. Hertz, Kraków 1997, s. 21-36.

2 J. Czapski, Świat w moich oczach, rozmowy przeprowadził P. Kłoczowski, Ząbki-Paris 2001, s. 174. Zob. też: „Trudno jest znaleźć człowieka, z którym się tak mówi, jak z tobą. To jakaś współdźwięczność na pewne nuty. Świadomość...” (tamże, s. 184).

${ }^{3}$ Niech poświadczą to trzy zdania z korespondencji z Joanną Pollakówną, której Czapski dziękuje za wrażliwą lekturę jego tekstów i za artykuły o jego malarstwie: „Nie widzę, by ktoś potrafił głębiej, rzetelniej wniknąć w moje teksty i szlachetniej, głębiej w nich podkreślić to, co dla mnie najważniejsze i które próbowałem wyrazić między wierszami, aluzyjnie" (list z 7 grudnia 1980 roku); „Pisze Pani o podwójnym nurcie mojego pisania - ależ naturalnie, jednak to się zauważa tu tylko, jeżeli się czyta, jak Pani, między wierszami”. [Wszystkie podkreślenia/wyróżnienia w cytatach, o ile nie zaznaczono inaczej, pochodzą od ich autorów] (list z 2 lutego 1981 roku); „Dlaczego to Pani piszę - bo Pani jedna między wierszami dotarła do nurtu, który jedyny nadaje sens memu życiu - inaczej czym jest życie?” (list z 3 lutego 1983 roku). Cytowane listy Józefa Czapskiego znajdują się w Archiwum Pollakówny w Muzeum Literatury w Warszawie, nr inw. 5058.

${ }^{4}$ Zob. J. Zieliński, Józef Czapski. Krótki przewodnik po dtugim życiu, Warszawa 1997, s. 69.

5 Zob. na przykład „Myślę, że wiem, co chciałeś mi powiedzieć Twoimi oczami, uśmiechem, łzami. Myślę, że wiem, najważniejsze" (Myślę, że wiem najważniejsze. Czapski-Collin, wybór listów, tłum. A.S. Sawicki, Kraków [1990], s. 33).

${ }^{6}$ Pisał o tym między innymi Marcin Jurek w artykule Parawany emigracyjnej oczywistości. Wymiary wygnania w pismach Józefa Czapskiego [w:] Pisarz na emigracji. Mitologie, style, strategie przetrwania, red. H. Gosk, A.S. Kowalczyk, Warszawa 2005, s. 213-225.

7 R. Sowińska, „Zachować spokój wewnętrzny i pracować nad soba... ” Filozofia twórcza Józefa Czapskiego [w:] Pisarz na emigracji..., dz. cyt., s. 234. 
Korespondencja z różnymi adresatami ${ }^{8}$ dowodzi, że autor Tumultu i widm nigdy nie zapomniał o swej kondycji emigranta, a to, że nie analizował tej kwestii wprost, świadczy właśnie o tym, jak bardzo istotna była dla niego, jak głęboko uwewnętrzniona i jak trudno było mu o niej mówić.

Dla Józefa Czapskiego wybór Polski jako ojczyzny nie był oczywisty. W domu mówiono po polsku, ale dbano też o znajomość francuskiego i niemieckiego, zaś wykształcenie zdobyte na rosyjskim uniwersytecie miało mu umożliwić dalszą karierę (rozpoczął studia prawnicze na Uniwersytecie Petersburskim). Pochodził z wielonarodowej rodziny i, korzystając z licznych koneksji, mógł zostać obywatelem świata niezwiązanym szczególnie z żadnym krajem, a zwłaszcza z Polską, której, gdy dorastał, nie było na mapie Europy9 ${ }^{9}$ Wśród jego przodków pojawiają się między innymi:

wykonawca rozbiorów Polski z rozkazu Katarzyny ambasador Otto Magnus Stackelberg, i konfederat barski Franciszek Stanisław Kostka Czapski. W je[go] własnym pokoleniu mamy na jednym krańcu wuja Jerzego Cziczerina, pierwszego komisarza spraw zagranicznych ZSRR, na drugim chyba Emeryka Czapskiego, baliwa maltańskiego, którego zbiory (...) nawiązują do napisu nad muzeum Hutten-Czapskich w Krakowie: Monumentis Patriae - Naufragio Ereptis ${ }^{10}$.

Józef Czapski mógł równie łatwo być tym wszystkim: albo bolszewickim komisarzem, albo kawalerem maltańskim, a jeśli chodzi o narodowość, to Polakiem, Rosjaninem, Niemcem, Austriakiem, Francuzem, Białorusinem, z wszelkimi możliwymi kombinacjami, na przykład bolszewickim komisarzem w Mińsku zwalczającym białoruski nacjonalizm. W dodatku niewiele brakowało, żeby z powodu swego pacyfizmu został dezerterem z wojska polskiego ${ }^{11}$, a zatem zaprzeczeniem patrioty. A jednak...

8 W artykule uwzględniam zarówno publikowaną (Jan Cybis, Katarzyna i Zbigniew Herbertowie, Ludwik Hering, Janusz Marciniak), jak i niepublikowaną (Czesław Miłosz, Joanna Pollakówna) korespondencję Czapskiego, związaną z interesującym mnie tu zagadnieniem. Adresy bibliograficzne i archiwalne podaję przy kolejnych cytatach.

${ }^{9}$ Historię i koligacje rodziny opisuje siostra Józefa, Maria Czapska [w:] tejże, Europa w rodzinie. Czas odmieniony, wstęp A. Zagajewski, Kraków 2004.

${ }^{10}$ K. Jeleński, Dziat wód [w:] tegoż, Chwile oderwane, wybór i oprac. P. Kłoczowski, Gdańsk 2007, s. 94-95.

${ }^{11}$ Perturbacje związane z odejściem z wojska wynikające z pacyfistycznych przekonań inspirowanych Tołstojowską publicystyką, powstanie chrześcijańskiego falansteru w rewolucyjnym Petersburgu i powrót do polskich oddziałów po rozmowie z Mereżkowskim - Czapski wielokrotnie relacjonował. Ten czas można uznać za właściwy okres jego ludzkiego i patriotycznego dojrzewania. Zob. na przykład W. Karpiński, Portret Czapskiego, Wrocław 1996, rozdz. Świadek wieku, s. 5-27. 
A jednak wybiera Polskę i świadome zaangażowanie w walkę o nią. Według jego własnych słów dopiero lektura Legendy Mtodej Polski w 1919 roku w Krakowie prowadzi go do głęboko świadomego wyboru ${ }^{12}$, czego świadectwo znajdujemy między innymi w liście do Czesława Miłosza:

Dlaczego Ci tak długo piszę specjalnie o Brzozowskim, do którego od lat nie wracam (poza Pamiętnikiem) i którego Legendę boję się, że już nie potrafiłbym czytać, bo będąc młodym pryncypialnym Tołstojowsko-Romain-Rollandowskim internacjonalistą i bardzo gardząc w duszy Polakami tak prowincjonalnymi (którzy dla mnie byli Polska) odkryłem w poczekalni u dentysty Legendę i to była rewolucja w moim życiu, nie tak rewolucja, ile odkrycie i krystalizacja - odkrycie moich powiązań i ,genealogii” polskiej ${ }^{13}$.

Konsekwencją tego odkrycia były kolejne decyzje, które doprowadziły go przez Starobielsk do armii Andersa, a po wojnie - do pracy na rzecz paryskiej „Kultury” i życia na emigracji, będącego dojmująco bolesnym, lecz w pełni świadomym wyborem.

W opublikowanym już po śmierci artysty wywiadzie pada pytanie: „Ale na wystawach występuje Pan jako Francuz?”, które spotkało się z kategoryczną odpowiedzią: „Nigdy w życiu! Jestem Polak i koniec. Podziwiam Francuzów, ale oni na pewno nie są obok mnie. Są naprzeciwko. Obok mnie są Polacy"14.

W obozie Starobielsk w chwili rozładowania, 5 IV 1940 r., było 3920 oficerów wraz z kilkudziesięcioma więźniami cywilnymi i około 30 podchorążymi i chorążymi. Uratowało się spośród nich 79. Jestem jednym z nich ${ }^{15}$

${ }^{12}$ Najobszerniej pisze o tym Czapski w eseju O Brzozowskim [w:] tegoż, Tumult i widma, posłowie A. Zagajewski, Kraków 2017, zwł. s. 330-331.

${ }^{13}$ List do Czesława Miłosza z 14 marca 1956 roku. Listy Józefa Czapskiego do Czesława Miłosza znajdują się w archiwum poety - w Beinecke Library, sygn. GEN MSS 661. Publikację korespondencji Miłosz-Czapski, przygotowuje Wydawnictwo Słowo/obraz terytoria, w serii „Biblioteka Mnemosyne”. Podobną deklarację spotykamy w o 30 lat późniejszej korespondencji z Januszem Marciniakiem: „[Brzozowski - dop. A.B.] w Legendzie Mtodej Polski poddał nie tylko kategorycznej krytyce, ale prawie likwidacji moje środowisko. I właśnie dlatego się w nim zakochałem, bo zupełnie inną Polskę mi objawił, która stała się moją przez niego (list z 27 maja 1986 roku); „Dla mnie to był piorun, cały mój [powrót] do Polski jemu zawdzięczam. Legenda Mtodej Polski druzgocąca krytyka mojej Polski wygodnej i bezmyślnej” (list z maja 1986 roku) (J. Czapski, Listy o malarstwie, red. M.M. Bieczyński, J. Marciniaka, Poznań 2019, s. 30, 20).

${ }^{14}$ J. Czapski, Wyrazić ból [w:] E. Dzikowska, Artyśsi mówiq̨. Wywiady z mistrzami malarstwa, Warszawa 2011, s. 36.

15 J. Czapski, Wspomnienia Starobielskie [w:] tegoż, Na nieludzkiej ziemi, posłowie N.S. Lebiediewa, Kraków 2017, s. 9. 
- to początek relacji Czapskiego z pobytu w obozie jenieckim, ujawniający także jeden z powodów uniemożliwiających powrót do kraju, pozostającego „w radzieckiej strefie wpływów". Publikacja Na nieludzkiej ziemi $\left(1949^{16}\right)$ i ujawnienie prawdy o losie polskich oficerów ostatecznie przypieczętowały wygnańczy los jej autora, którego świadectwo, mimo ewidentnych dowodów winy NKWD, było wielokrotnie kwestionowane. O jednym z takich przypadków, z 1966 roku (!), wspomina w liście do Zbigniewa Herberta:

Szarpałem się w Radiu Francuskim o Katyń z nieuczciwymi nie tylko rozmówcami, ale historykami, którzy [słowo nieczytelne] teraz chcą prowadzić nieuczciwe dyskusje, pomyśl, że mnie przeciwstawiali anonimowy list [słowo nieczytelne], który zaręczał, że Katyń to Niemcy!!17

Wiele lat później, rozważając możliwość wydania dzienników, pisał do Pollakówny:

Te dzienniki zaczynają się od wyjścia z Rosji, dawniejsze (w obozie) są częściowo wykorzystane w 2 książeczkach po francusku, tzn. Proust contre le déchéance mój odczyt mówiony w obozie po francusku i Souvenir de Starobielsk też po francusku, ale tłumaczone z polskiego. Napisz mi, czy te książeczki masz (bo ja je wcale do Polski nie wysyłałem (ze strachu))!! Jeżeli nie masz, zaraz Ci wyślę $e^{18}$.

Dopowiedzmy, że obawy nie dotyczyły jego samego, ale losu potencjalnych adresatów, a także pozostającej w Polsce rodziny artysty. Troska o przyjaciół i bliskich pogłębiała emigracyjną samotność, uniemożliwiając dzielenie się tym, co odczuwane, jako najistotniejsze.

16 Por. „....nakład w całości wykupiła i zapewne zniszczyła Ambasada Sowiecka w Paryżu” (J.S. Pasierb, Józef Czapski - Polak, artysta, chrzéscijanin, „Więź” 1993, nr 3 (413)).

17 J. i M. Czapscy, K. i Z. Herbertowie, Korespondencja, odczytał i przypisami opatrzył J. Strzałka, Warszawa 2017, s. 24, list z 9 listopada 1966 roku. Szerzej o poczuciu zobowiązania wobec tych, którzy odeszli, pisze Czapski w przejmującym eseju Łańcuch niewidzialny [w:] tegoż, Tumult i widma, dz. cyt., s. 101-116. Tytułowa metafora będzie wielokrotnie wykorzystywana przez Czapskiego do opisu historycznej sytuacji Polski, której kolejne pokolenia wiąże z ofiarami za wolność „łańcuch niewidzialny”. Metafora ta trawestowała bardziej dosadne wyrażenie mentora i przyjaciela Czapskiego - Dymitra Fiłosofowa: „Wiele lat temu, koło 28-30 roku mówiono, że Piłsudski odejść chce w rozgoryczeniu ze swojego stanowiska (...) i wtedy nasz przyjaciel Rosjanin nam powiedział: "Nie odejdzie - jego trupy trzymają«. Trupy trzymają Was oboje, Ciebie i Kasieńkę - i trzymają nas, i trzymają pomimo wszystko Miłosza - choć wierzga” (J. i M. Czapscy, K. i Z. Herbertowie, dz. cyt., s. 56-57, list z grudnia 1969-stycznia 1970 roku).

${ }^{18}$ List do J. Pollakówny z 24 lipca 1988 roku, Archiwum Joanny Pollakówny w Muzeum Literatury w Warszawie, nr inw. 5058. 
Gdy tylko po Październiku 1956 roku pojawia się szansa na bliższy kontakt z Polską - wokół potencjalnego wyjazdu koncentrują się projekty Czapskiego, o czym donosi przyjacielowi - Ludwikowi Heringowi:

Moje projekty malarskie: Wystawa w czerwcu w Poznaniu, a potem w Warszawie. Nie jadę ja - tak jest ustalone teraz - ale coraz bardziej jest uczucie, że jeżeli stan dzisiejszy się nie odwróci - przyjazd do Polski zdaje mi się coraz bardziej możliwy ${ }^{19}$.

Ale już, w liście do tego samego adresata z datą o pół roku późniejszą, czytamy:

Mój przyjazd do Polski nie był możliwy i jeżeli to boli dotkliwie, to że się nie spotkamy, ale jeszcze nigdy od 39 roku nie czułem, że to spotkanie jest „ręką dosiężne”, że jest możliwe i że będzie ${ }^{20}$.

Ta sama prawidłowość dotyczyła przyjaciół, których usiłował zaprosić do siebie. Starał się to robić nie sam, ale przez instytucje, w związku z oficjalnymi wydarzeniami - jak było w przypadku Heringa i jego przyjazdu na Festiwal Sztuki Awangardowej ${ }^{21}$ jako członka Teatru Osobnego (Miron Białoszewski, Ludwik Hering, Ludmiła Murawska). Do przyjazdu nie doszło, gdyż - jak tłumaczył Hering:

nazwisko i pieniądze, które się zjawiło przy zaproszeniu do Paryża, ma niewątpliwy sens polityczny - i niewłaściwością byłoby z tego korzystać. - Wyjaśniono to nam obiektywnie i przyjaźnie i skutek - to złożone podziękowanie za propozycję ${ }^{22}$.

Kiedy otrzymał recenzje po wystawie z 1986 (Warszawskie Muzeum Archidiecezjalne) - pisał do zaangażowanej w jej przygotowanie Joanny Pollakówny:

z moją prawie ślepotą jestem bezsilny i tylu osobom chciałbym napisać, wyrazić całą moją wzruszoną wdzięczność, która mnie po jakiemuś odkorkowała i dała

${ }_{19}$ J. Czapski, L. Hering, Listy 1939-1982, t. 1: 4 września 1939-16 stycznia 1959, oprac. L. Murawska-Péju, D. Szczerba, J. Juryś, P. Kłoczowski, posłowie A. Zagajewski, Gdańsk 2016, s. 248 , list z 30 grudnia 1956 roku.

20 Tamże s. 264, list z 12 czerwca 1957 roku, s. 264.

21 Por. „który naturalnie nie ma nic z jakąkolwiek polityką czy propagandą do czynienia” (J. Czapski, L. Hering, Listy 1939-1982, t. 2: 28 stycznia 1959-26 czerwca 1982, oprac. L. Murawska-Péju, D. Szczerba, J. Juryś, P. Kłoczowski, posłowie A. Zagajewski, Gdańsk 2017, s. 89, list z 4 listopada 1960 roku).

${ }^{22}$ Było to zaproszenie od Konstantego A. Jeleńskiego [przyp. red. listów]. Tamże, s. 97, list z 5 lutego 1961 roku. 
poczucie, że „samotność, cóż po ludziach, czym śpiewak dla ludzi” przestało być moim mottem i że właściwie chodziło mi zawsze o jedną wystawę, o wystawę w Polsce ${ }^{23}$.

\section{W podobnych słowach dziękował Januszowi Marciniakowi:}

Mam wiadomości o wystawie ustne i przyznam, że mnie szalenie wzruszyły, jakby się we mnie coś odkorkowało. „Samotność! cóż po ludziach! czym śpiewak dla ludzi?” było moim przez lata intymnym mottem, ale listy z kraju i właśnie Twoje słowa zadały krzyczący kłam. Jeżeli to stanowisko uogólnić na całe życie, tej jakiejś odpowiedzi człowiek, chce czy nie chce, potrzebuje! Wyście, wy, prawnuki, mi ją dali ${ }^{24}$.

Wzruszenie było tym większe, że jeszcze rok wcześniej ten pomysł wydawał się niewykonalny:

Projekt wystawy mojej w Polsce zdaje mi się coraz mniej realny. Woźniakowski robi co może, żeby to się udało, ale muszę przyznać, że coraz mniej o ten projekt dbam, bo nie wierzę, bym mógł wtedy do Polski dojechać, a że po mojej śmierci zrobić taką wystawę będzie nieskończenie łatwiejj ${ }^{25}$.

Jak wielką wagę przywiązywał do kontaktu z polskim odbiorcą i możliwości pokazania własnych prac w Polsce świadczy też list do przyjaciela kapisty, Jana Cybisa:

A malarsko przyznam $\mathrm{Ci}$, że tylko czuję siebie w malarstwie polskim, myślę, że może miejsce tam będę miał w łańcuchu, w którym jesteśmy wszyscy, a to co robię teraz, gdzie zdaje mi się dopiero [przez - dop. A.B.] ostatnie 20 lat moja praca się

${ }^{23}$ List z 22 maja 1986 roku. Dla porządku powiedzmy, że pierwsze powojenne wystawy Czapskiego w Polsce odbyły się 1957 roku (Warszawa, Poznań). W niedatowanym wywiadzie, który na podstawie treści sytuować można między 1981 a 1985 rokiem, Czapski z przejmującą rezygnacją mówił: „samo moje malarstwo jest w Polsce zupełnie nieznane i to mnie boli najbardziej. Jacek Woźniakowski uważał, że powinienem mieć wystawę w Muzeum Narodowym w Krakowie. Przed ogłoszeniem stanu wojennego była taka chwila, że wydawało się to nawet bliskie. Sądzę, że za mojego życia do tego nie dojdzie. Przyjąłem to, ale przyznam szczerze, to właśnie jest dla mnie największym brakiem. Liczę, że gdy umrę, co nastąpi chyba niezadługo, będzie łatwiej zrobić moją wystawę w kraju" (Rozmowa z Józefem Czapskim [w:] J. Jędrychowska [właśc. K. Kijowska], Widzieć Polskę z oddalenia, b.m.w. 1990, s. 46).

${ }_{24}$ J. Czapski, Listy o malarstwie, dz. cyt., list z maja 1983 roku.

25 List do J. Pollakówny z 14 maja 1985 roku, Archiwum Joanny Pollakówny w Muzeum Literatury w Warszawie, nr inw. 5058. 
jakoś scaliła i rozrosła. Chciałbym, żeby moje płótna najlepsze były w Polsce, żadne Ameryki, żadna Francja mnie nie kuszą ${ }^{26}$.

Podobne pozytywne emocje, a wcześniej niepewność towarzyszą krajowym publikacjom fragmentów jego dzienników i tomu esejów - najpierw w drugim obiegu, potem już w oficjalnym. Gdy przygotowująca do druku tom $\mathrm{Pa}$ trząc Joanna Pollakówna prosi autora o kilka słów wprowadzenia - ten odpowiada: „Żeby napisać wstęp dziś DLA Polski mnie onieśmiela i wzrusza” ${ }^{27}$, zaś po otrzymaniu listów z kraju pisze do redaktorki tomu:

Przez wiele lat malowałem, tem bardziej pisałem z przekonaniem, że „samotność, cóż po ludziach, czym śpiewak dla ludzi” i pierwsze reakcje z Polski głównie po urywkach moich dzienników zrobiły na mnie wrażenie jakiejś szczęśliwej rewelacji. Sam się zgorszyłem, dlaczego tak bardzo mnie to wzruszyło i jeżeli tak bardzo, że zrozumiałem, że jest to największą nagrodą, o której nawet marzyć nie śmiałem. Obrazy moje rozmiecione po świecie, nie wiem, czy kiedy i które znajdą się w Polsce, a przecie naprawdę o to tylko mi chodzi, ale teksty pisane doszły i każdy list nieznajomego, który te teksty przeżył, przyjmuję z największą wdzięcznością ${ }^{28}$.

Nie chodzi tu jedynie o spełnienie pragnienia artysty oczekującego odpowiedzi na swą twórczość. Wszystkie sygnały z kraju są dla niego potwierdzeniem - jakkolwiek górnolotnie by to nie brzmiało - sensu istnienia. W 1951 roku, pisał Czapski w eseju o innym emigrancie:

Poniżenie każdej emigracji, które trwa nie dni, ale lata, rodzi nie tylko gorycz swary i nienawiść - rodzi także światło.

Im więcej myślę o emigracji, tym więcej mi się zdaje, że takie zjawisko siły twórczej w pustyni wygnania, to najwyższe usprawiedliwienie tułaczki emigracyjnej ${ }^{29}$.

Doświadczenie pustyni nieobce było i samemu Czapskiemu ${ }^{30}$ - była to nie tylko pustynia wygnania i wydziedziczenia w sensie dosłownym, ale także

${ }^{26}$ J. Czapski, List do Jana Cybisa [w:] „Żadne Ameryki, żadna Francja”. Obrazy Józefa Czapskiego z kolekcji Krzysztofa Musiata. Swoje spotkania z Czapskim wspomina Jacek Cybis. Przyjaciót artysty z Komitetu Paryskiego przypominaja na wystawie ich portrety wtasne. Galeria aTAK, Warszawa 5-30 X 2017 [katalog wystawy], s. 15.

${ }^{27}$ List z 7 maja 1985 roku, Archiwum Joanny Pollakówny w Muzeum Literatury w Warszawie, nr inw. 5058.

${ }^{28}$ List do J. Pollakówny z 29 lutego 1988 roku, Archiwum Joanny Pollakówny w Muzeum Literatury w Warszawie, nr inw. 5058.

29 J. Czapski, „Montagnes Russes” [w:] tegoż, Czytając, wybór, oprac. i wstęp J. Zieliński, Kraków 2015, s. 169. Esej dotyczy Aleksieja Remizowa, a dedykowany jest również emigrantowi - Dymitrowi Fiłosofowowi.

${ }^{30}$ Szerzej piszę o tym w przygotowywanej książce poświęconej doświadczeniu religijnemu w twórczości Czapskiego. 
dobrowolne wydziedziczenie z tego, na czym najbardziej mu zależało, na rzecz tego, co uważał za wyższą wartośśc ${ }^{11}$, oraz - postępujące z czasem osamotnienie związane z utratą kolejnych bliskich sercu osób. I on często heroicznie walczył o utrzymanie siły twórczej (czego najbardziej przejmującym świadectwem są zapisy dziennikowe i tysiące listów do różnych adresatów), dlatego opinie o tym, czemu poświęcił swe życie, i co uważał za swoje właściwe powołanie miały tak istotne znaczenie, były bowiem miarą tego, czy potrafił nie odwracać wzroku, nie uciekać przed trudami losu, a - mówiąc słowami jednego z jego mistrzów - czy umiał „odejrzeć Nieszczęściu”32.

Wyjątkowe miejsce wśród tych pisanych rozmów artysty zajmuje jego dziennik, będący przestrzenią nieustających przez lata dyskusji z samym sobą i setkami innych osób, które - często mimo różnicy czasu i przestrzeni, jaka go od nich dzieli - traktuje Czapski jako intelektualnych partnerów, a często życiowych mistrzów. Na kartach kolejnych kajetów znajdujemy również wprost szkice listów „do”, ale i same listy „od” - najważniejsze, spośród tych ostatnich, pieczołowicie wklejane i znów stanowiące punkt wyjścia „rozmowy”, prowadzonej w osobistych zapisach nie tylko ze względu na różne ograniczenia, ale także z wewnętrznej silnej potrzeby kształtowania siebie w nieustannym dialogu z Drugim. Wiele z tych rozmów, począwszy od najstarszych zachowanych zapisów, dotyczy Polski.

Przebywając w szpitalu amerykańskim w Meszhedzie jako żołnierz armii Andersa (po fiasku poszukiwań zaginionych polskich oficerów), odpowiedzialny za Biuro Wydawnictw II Korpusu, notuje wcześniejsze obserwacje:

Nasi się zdaje, że za prędko zarażają kolonialną mentalnością Europejczyków poza Europą (...).

31 Zob. na przykład refleksje dotyczące konieczności pełnego zaangażowania w pracę na rzecz II Korpusu: „[Bagdad] 8 I [1943]. (...) jeżeli mam się czegoś wyrzec, nie robić z tego na zewnątrz dramatu i w aureoli tego dramatu tłumaczyć swoje niedociągnięcia i błędy (...), tu to musi być ofiara, dla mnie ofiara z malarstwa i jeszcze z czegoś" (J. Czapski, $Z$ dziennika 1942 1943, odczytał z rękopisu J. Nowak, wybór i oprac. M. Nowak-Rogoziński, „Konteksty. Polska Sztuka Ludowa” 2018, nr 3, s. 238).

32 Chodzi tu o kolejny ze złotych cytatów Czapskiego - tym razem pochodzący z Norwidowego Fatum. „Przymuszając się do spojrzenia w oczy temu nieszczęściu, możesz to nieszczęście przemienić. Nie przekreślić. Jak przekreślasz, żyjesz jak większość ludzi, którzy mają szafy, a w tych szafach jest okropieństwo. Więc zamykasz na klucz... tak nie powinno być! (...) To ja ci mówię, ja stary człowiek: jak masz nieszczęście, nie uciekaj, patrz, patrz w to nieszczęście. I wtedy ono jakoś dojrzewa i odchodzi” (J. Czapski, Świat w moich oczach, dz. cyt., s. 173-174, 184). 
(...) uczucie, że właściwie całe panowanie w Indiach wyrasta na niewolnictwie, na przywilejach Herrenvolku i że my Polacy w pośpiechu zapisujemy się tam, jako właściwie przedstawiciele tego Herrenvolku również. Dlaczego ci Persowie nawet tu w szpitalu tak się cieszą, tak są grzeczni, jak widzą, że ja się ${ }^{33}$ chcę uczyć ich wyrażeń, jak dopytuję się o ich kraj i oni czują, że mówię z nimi, ani chwili nie przychodzi mi do głowy, że jestem „wyższą” istotą.

Czy naprawdę ten dystans, który mają na Wschodzie Anglicy i który może jest dla nich konieczny, żeby utrzymać pod swoim panowaniem kolosalne imperium, czy ten dystans ma jakiś sens w stosunku Polaka do człowieka wschodniego, czy nie byłoby w naszym interesie jako państwu nieobciążonemu na wschodzie przeszłością kolonialną postępować wręcz przeciwnie! ${ }^{34}$

Pobrzmiewa już tutaj - wyrażona wiele lat później w polemicznym wobec recenzji Miłosza z Cieni w pieczarze Stefana Kisielewskiego eseju Dwie prowokacje (1972) - głęboka tęsknota za tradycją Rzeczypospolitej Obojga Narodów ${ }^{35}$ i organiczna niechęć do najdrobniejszych nawet przejawów nacjonalizmu ${ }^{36}$. Jak głęboko poruszyła Czapskiego wypowiedź Miłosza, świadczy też korespondencja, w której o wiele silniej niż w tekście publikowanym wybrzmiewa oburzenie:

Dziwisz się, że podszedłem do Twojego artykułu emocjonalnie? Stempowski usunięty z polskiej tradycji kulturalnej jako kosmopolita rodem z Ukrainy i fałszywy salonowiec (zaledwie upraszczam), Polak widziany jako istota zdolna do... nacjonalizmu jedynie do czego jeszcze dodajesz w liście, że sprawy te dla Ciebie „należą do przeszłości”. (...) Ale Twój stosunek do książki Stalińskiego wcale do przeszłości nie należy, piszesz jednak o nim, jakby sprawy tam poruszone były definitywnie poza Tobą, poza Twoją odpowiedzialnością, bo to przeszłość już załatwiona! Dotknęłoby mnie to o wiele bardziej jeszcze gdybym wierzył, że to dla Ciebie sprawy naprawdę zamknięte. (...)

31 XII

PS

Odczytuję ten list przed wysłaniem i chciałbym jeszcze napisać go inaczej, bez goryczy, ale już nie mam na to sił. Już mi na nie sił i czasu nie starczy, to jest starość.

33 W druku błędne odczytanie: „ja nie chcę uczyć”. Dziękuję za zwrócenie uwagi na tę logiczną niekonsekwencję recenzentowi artykułu. W rękopisie: „ja się chcę uczyć”.

${ }^{34}$ J. Czapski, $Z$ dziennika 1942-1943, dz. cyt., s. 235 [zapis z 12 września 1942 r.]. [W oryginalnym zapisie dziennikowym dwa końcowe słowa: „wręcz przeciwnie” - są podkreślone, a zdanie zamyka pytajnik, nie wykrzyknik].

${ }^{35}$ J. Czapski, Dwie prowokacje [w:] tegoż, Czytając, dz. cyt., s. 382. Esej jest polemiką z artykułem Miłosza Duże cienie, który powstał w odpowiedzi na książkę Stalińskiego (Kisielewskiego) - Cienie w pieczarze.

${ }^{36}$ Pisze o tym we wstępie do Czytając Jan Zieliński (tenże, Kolejność ważności, wstęp [do:] J. Czapski, Czytając, dz. cyt., s. 10-11). 
A sprawy, o których Ty piszesz jak o przeszłości jakby obojętnie, mnie z wiekiem bolą coraz bardziej ${ }^{37}$.

Przytaczam jeden tylko fragment $\mathrm{z}$ obszernego listu ${ }^{38}$, gdyż wydaje się on szczególnie istotny dla Czapskiego, także w wymiarze osobistym. Wielokrotnie bowiem i on sam ze względu na wielonarodowe koneksje rodzinne nazywany był kosmopolitą - niekoniecznie w pejoratywnym znaczeniu, jednak określenie to musiało go boleśnie dotykać, gdyż świadomie i nieodwołalnie wybrał Polskę na swoją ojczyznę ${ }^{39}$. Był to wybór tak głęboko wewnętrzny i „nie na pokaz”, a jednocześnie do tego stopnia determinujący wszystkie kolejne życiowe decyzje, że wydawało się oczywiste, iż ten rodzaj patriotyzmu, poświadczany życiem, nie deklaracjami, nie wymaga dodatkowych „uzasadnień”. Najbardziej jednak dotyka Czapskiego odsunięcie w przeszłość zagadnień, które dla niego zawsze pozostawały żywe, a doceniając znaczenie twórczości Miłosza i jego wpływ na odbiorców - oczekiwał od poety tym większego zaangażowania.

W 1982 roku, gdy w Polsce trwa stan wojenny, pisze do Zbigniewa Herberta w odpowiedzi na dedykowany mu wiersz 17 września:

Zbyszku, nie wiem, jak Ci powiedzieć, jak się zabrać do tego, żeby Ci powiedzieć moje wzruszenie po tym jak doszedł do mnie Twój wiersz i że mnie go poświęciłeśt0 ${ }^{40}$, dotyka mnie do głębi. Mam go blisko siebie stale, co w ogóle w ostatnim położeniu więcej niż ktokolwiek dało mi fizyczne uczucie tęsknoty, z którą, zdawało mi się, że sobie poradziłem. Fizycznej tęsknoty nie za tym czy innym człowiekiem, ale [za - dop. red. korespondencji] Polską cielesną dzisiejszą, mnie znaną, przez parę cudownych dla mnie przykładów, dla mnie, bo poczułem jakiś żywy moralny kontakt, byłem już pewny, że jeszcze przyjadę do Was. Dziś już nie widzę tego i może pierwszy raz poczułem, co to jest emigracja. Być na zawsze tak daleko od bezbronnej ojczyzny i naraz ciemne proroctwa i klątwy, i nasz los przemijający i kruchy, a jednocześnie patrząc szerzej, nie przemijający i nie kruchy. 39 rok oduczył mnie na zawsze optymizmu. Ale kiedy myślę o całym nowym pokoleniu,

37 List z 30 grudnia 1972 roku, List Józefa Czapskiego do Czesława Miłosza, Archiwum Czesława Miłosza - Beinecke Library (Yale University), sygn. GEN MSS 661.

${ }_{38}$ Zob. omówienie sporu korespondentów „o kondycję polskiego narodu” w artykule Andrzeja Franaszka Bronitem i bronię polskości innej na łamach „Tekstów Drugich” 2020, nr 6, s. 38-61 (artykuł ukazał się już po przyjęciu niniejszego artykułu do druku, dlatego nie mogłam odnieść się szerzej do jego treści, mimo zbieżności poruszanych zagadnień).

39 O takim niewątpliwym wyborze dokonanym przez Jerzego Stempowskiego przekonuje w eseju Dwie prowokacje.

${ }^{40}$ Chodzi o wiersz Herberta 17 września. 
zdaje mi się, że nie mam już na to sił. I Twoje słowa mnie po jakiemuś utwierdziły i uszczęśliwiły ${ }^{41}$.

Choć wizyta w kraju pozostała dla Czapskiego niespełnionym pragnieniem i niezaspokojoną tęsknotą, to świadomość, że jest obecny w pamięci kolejnych pokoleń, pozwalała zachować wiarę w sens istnienia, w to właśnie, że „w szerszym wymiarze” ludzki los nie przemija.

\section{Bibliografia}

Bielak A., Haupt Czapskiego [w:] Jestem bardzo niefortunnym wyborem. Studia i szkice o twórczości Zygmunta Haupta, red. A. Niewiadomski, P. Panas, Lublin 2018.

Czapscy J. i M., Herbertowie K. i Z., Korespondencja, odczytał i przypisami opatrzył J. Strzałka, Warszawa 2017.

Czapska M., Europa w rodzinie. Czas odmieniony, wstęp A. Zagajewski, Kraków 2004.

Czapski J., Dwie prowokacje [w:] tegoż, Czytając, wybór, oprac. i wstęp J. Zieliński, Kraków 2015.

Czapski J., List do Jana Cybisa [w:] „Żadne Ameryki, żadna Francja”. Obrazy Józefa Czapskiego z kolekcji Krzysztofa Musiata. Swoje spotkania z Czapskim wspomina Jacek Cybis. Przyjaciót artysty z Komitetu Paryskiego przypominaja na wystawie ich portrety wtasne. Galeria aTAK, Warszawa 5-30 X 2017 [katalog wystawy].

Czapski J., Listy do Czesława Miłosza, Archiwum Czesława Miłosza - Beinecke Library (Yale University), sygn. GEN MSS 661 [niepublikowane].

Czapski J., Listy do Joanny Pollakówny, Archiwum Pollakówny w Muzeum Literatury w Warszawie, nr inw. 5058 [niepublikowane].

Czapski J., Listy o malarstwie, red. M.M. Bieczyński, J. Marciniak, Poznań 2019. Czapski J., Łańcuch niewidzialny [w:] tegoż, Tumult i widma, posłowie A. Zagajewski, Kraków 2017.

Czapski J., „Montagnes Russes” [w:] tegoż, Czytając, wybór, oprac. i wstęp J. Zieliński, Kraków 2015.

Czapski J., O Brzozowskim [w:] tegoż, Tumult i widma, posłowie A. Zagajewski, Kraków 2017.

Czapski J., Świat $w$ moich oczach, rozmowy przeprowadził P. Kłoczowski, ZąbkiParis 2001.

Czapski J., Wspomnienia Starobielskie [w:] tegoż, Na nieludzkiej ziemi, posłowie N.S. Lebiediewa, Kraków 2017.

Czapski J., Wyrazić ból [w:] E. Dzikowska, Artyści mówią. Wywiady z mistrzami malarstwa, Warszawa 2011.

${ }^{41}$ J. i M. Czapscy, K. i Z. Herbertowie, dz. cyt., s. 87-88, list z 21 maja 1982 roku. 
Czapski J., Z dziennika 1942-1943, odczytał z rękopisu J. Nowak, wybór i oprac. M. Nowak-Rogoziński, „Konteksty. Polska Sztuka Ludowa” 2018, nr 3.

Czapski J., Hering L., Listy 1939-1982, t. 1: 4 września 1939-16 stycznia 1959, oprac. L. Murawska-Péju, D. Szczerba, J. Juryś, P. Kłoczowski, posłowie A. Zagajewski, Gdańsk 2016.

Czapski J., Hering L., Listy 1939-1982, t. 2: 28 stycznia 1959-26 czerwca 1982, oprac. L. Murawska-Péju, D. Szczerba, J. Juryś, P. Kłoczowski, posłowie A. Zagajewski, Gdańsk 2017.

Franaszek A., Bronitem i bronię polskości innej, „Teksty Drugie” 2020, nr 6.

Hofmannsthal H. von, List [w:] tegoż, Księga przyjaciót i szkice wybrane, wybór, tłum. i noty P. Hertz, Kraków 1997.

Jeleński K., Dziat wód [w:] tegoż, Chwile oderwane, wybór i oprac. P. Kłoczowski, Gdańsk 2007.

Jurek M., Parawany emigracyjnej oczywistości. Wymiary wygnania w pismach Józefa Czapskiego [w:] Pisarz na emigracji. Mitologie, style, strategie przetrwania, red. H. Gosk, A.S. Kowalczyk, Warszawa 2005.

Karpiński W., Portret Czapskiego, Wrocław 1996.

Myślę, że wiem najważniejsze. Czapski - Collin, wybór listów, tłum. A.S. Sawicki, Kraków [1990].

Pasierb J.S., Józef Czapski - Polak, artysta, chrześcijanin, „Więż” 1993, nr 3.

Rozmowa z Józefem Czapskim [w:] J. Jędrychowska [właśc. K. Kijowska], Widzieć Polskę z oddalenia, b.m.w. 1990.

Sowińska R., „Zachować spokój wewnętrzny i pracować nad sobą... ” Filozofia twórcza Józefa Czapskiego [w:] Pisarz na emigracji. Mitologie, style, strategie przetrwania, red. H. Gosk, A.S. Kowalczyk, Warszawa 2005.

Zieliński J., Józef Czapski. Krótki przewodnik po dtugim życiu, Warszawa 1997.

Zieliński J., Kolejność ważności, wstęp [do:] J. Czapski, Czytając, wybór, oprac. i wstęp J. Zieliński, Kraków 2015. 